Al-Bidayah : jurnal pendidikan dasar Islam

Volume 13, Number 1, June 2021

ISSN: 2549-3388 (online)

Available online at https://jurnal.albidayah.id

Submitted: September 6, 2020, Accepted: June 29, 2021

\title{
THE ROLE OF SOCIAL CAPITAL IN FOSTERING CHARACTER EDUCATION IN PRIMARY SCHOOLS: KI HADJAR DEWANTARA'S PERSPECTIVES
}

\author{
Heri Maria Zulfiati' ${ }^{1}$, Biya Ebi Praheto², Anselmus Sudirman³ \\ Universitas Sarjanawiyata Tamansiswa Yogyakarta, Indonesia ${ }^{1,2,3}$ \\ E-mail: heri.maria@ustjogja.ac.id ${ }^{1}$, biya.ebi@ustjogja.ac.id ${ }^{2}$ \\ anselmus.sudirman@ustjogja.ac.id ${ }^{3}$
}

DOI: 10.14421/al-bidayah.v13i1.555

\begin{abstract}
To foster character education in Indonesia, research on the role of social capital has become an urgent issue because character crisis is one of the growing concerns and recent stunning news stakes. National identity crises have shown anti-cultural behavior, anti-character, and less use of domestic social capital blatantly. This research aims to describe the role of social capital that determines the implementation of character education through Ki Hadjar Dewantara's perspectives. This qualitative research was designed as a case study using purposive sampling with individual resources such as headmaster, teacher, student representatives, school committee, parents, foundation management, and school supervisor. This research was conducted at Tamansiswa Primary School, Yogyakarta, Indonesia, from November 2017 to January 2018. The research result shows that the social capital role determines the implementation of character education, and in Ki Hadjar Dewantara's perspective, character education has been applied in all learning processes. Both intra-curricular and extracurricular activities support the school culture, and the family system is an integral part of habituation and exemplary character inculcation at school, family, and societal levels through mutual love, respect, assistance, and help. The obliged elements of social capital in embodying character education are trust, norm, and network.
\end{abstract}

Keywords: character education; Ki Hadjar Dewantara; primary school; social capital

\section{INTRODUCTION}

The current portraits of the world of education in Indonesia showed that the education system is considered less serious or has failed in educating the nation's character. This indication can be seen from the many problems related to the nation's character, such as drug abuse cases among school children, promiscuity, crime, acts of violence such as persecution, brawls, fighting against one another, and violent streets, or often called clit. ${ }^{1}$ The problem of character sometimes has started to show violence from destructive actions such as violence, arson, murder, kidnapping, rape, terrorism. These phenomena are indications that something is wrong in the world of education.

${ }^{1}$ Indonesian Child Protection Commission (KPAI), "Data Kasus Pengaduan Anak 2016 - 2020 | Bank Data Perlindungan Anak," 2021, https://bankdata.kpai.go.id/tabulasi-data/data-kasus-pengaduananak-2016-2020. 
Another problem in the world of education is that at present, there is much shocking news related to the behavior that comes out of the noble values of the nation's culture carried out by students starting from the elementary school level (SD) even to students in Higher Education (PT). For example, they are familiar with smoking, drunkenness, drugs, and recklessness at school age, even until school children get pregnant out of wedlock. They are free to socialize without boundaries, and ethics, courtesy, respect for teachers, tepo seliro (tolerance) are no longer visible. From time to time, these noble values begin to fade, fade lose their substantive meaning and seem to become meaningless symbols, and lead to destruction. Beginner Lecturer research conducted by researchers entitled "Implementation of Character Education in School Culture through the Teaching Values of Ki Hadjar Dewantara at Taman Muda Ibu Pawiyatan Elementary School, Yogyakarta”. The research results conducted by researchers in 2016 show that the implementation of character education through school culture in the form of learning related to local cultures, such as dance, music, artistic painting or drawing, and learning Javanese. ${ }^{2}$ Barriers to implementing character education In this school culture and advances in information technology that students misuse, family factors that do not supervise students' behavior, less educated family factors, and society that does not support the achievement of character education goals also affect. Seeing the above phenomenon, researchers feel the need and importance of holding further research related to strengthening social capital because social capital and cultural capital have a major influence on character education. This argument is in line with the research conducted by Dwiningrum ${ }^{3}$ in the Asian Social Science Journal that social capital as a collective strength must be reconsidered as a sociocultural strength that strengthens the character of the nation. The element of social capital plays an important role in shaping the character of education in families, schools and communities. This capital can build character 'synergistically bridging social capital', the purpose and function of character education can be obtained optimally.

Cultural issues and national character education are now under the spotlight due to some problems leading to certain striking features:

\footnotetext{
${ }^{2}$ Heri Maria Zulfiati, Suyanto Suyanto, and Hadjar Pamadhi, "Modal Budaya Sebagai Penguat Pembentukan Karakter Berbasis Ajaran Ki Hadjar Dewantara di Sekolah Dasar," KELUARGA: Jurnal Ilmiah Pendidikan Kesejahteraan Keluarga 5, no. 1 (August 14, 2019): 190-201, https://doi.org/10.30738/keluarga.v5i1.3093.

${ }^{3}$ Siti Irene Astuti Dwiningrum, "Nation's Character Education Based on the Social Capital Theory," Asian Social Science 9, no. 12 (October 30, 2013): p144, https://doi.org/10.5539/ass.v9n12p144.
} 
(1) increased violence and anarchy, (2) theft; (3) fraudulent acts; (4) a waiver of the applicable rules; (5) studying between students; (6) intolerance; (7) improper language and speech worries, (8) too early sexual maturity and strong influence of strong peer-groups in violence, (9) increased self-destructive behaviour (such as drug, alcohol and sex use free), and (10) increasingly blurred moral and bad guidelines. $^{4}$

Various alternatives are proposed to overcome or at least reduce the socio-cultural issues and national character education in social capital. These conditions, if left unresolved, will certainly damage the school-based social capital because social and cultural capitals are an important element expected to help solve existing problems of the character crisis. Character education is set to prepare citizens in diverse communities to have commendable characters to build long-term social capital. ${ }^{5}$ Similarly, it articulates that social capital is needed in the character education process because social interaction requires social energy to be successfully optimal in the macro and micro scales. Thus, it is clear that social capital affects the attainment of character education goals in trust between members and cooperation between institutions. ${ }^{6}$

The facts and findings of several studies conclude that social capital has a very important reciprocal relationship with learners' education and character formation. ${ }^{7}$ In addition, the relationship between education and social capital is assumed to be a driving force in building the character of learners following national education objectives. According to Zulfiati, H.M (2019) ${ }^{8}$, good and quality characters need to be formed and socialized from an early age, especially elementary school age. Elementary school-age children are the right time to develop values, attitudes, and behaviours that exude good morals, noble or noble character.

3 Thomas Lickona. Educating For Character: How Our Schools Can Teach Respect and Responbility. In U. Wahyudin (Ed.) (keempat). (Jakarta: Bumi Aksara, 2015), 20-30.

${ }^{5}$ Suyanto. "Social Capital : Kedaulatan Rakyat." News. June 2017, 1.

${ }^{6}$ Siti Irene Astuti Dwiningrum, "Nation's Character Education Based on the Social Capital Theory," Asian Social Science 9, no. 12 (October 30, 2013): p144, https://doi.org/10.5539/ass.v9n12p144.

${ }^{7}$ Kurotul Aeni, Zamroni Zamroni, and Darmiyati Zuchdi, "Pendayagunaan Modal Sosial Dalam Pendidikan Karakter," Jurnal Pembangunan Pendidikan: Fondasi Dan Aplikasi 4, no. 1 (December 21, 2016): 30-42, https://doi.org/10.21831/jppfa.v4i1.9819; Kristi Wardani and Yohana Sumiyati, "Implementasi Pendidikan Karakter Melalui Pengelolaan Modal Sosial Pada Pembelajaran Di Sekolah Dasar", Seminar Nasional Riset Inovatif II (Jakarta: Universitas Mercubuana, 2014), 222-29, http://digilib.mercubuana.ac.id/manager/t!@file_artikel_abstrak/Isi_Artikel_235856818721.pdf.

${ }^{8}$ Heri Maria Zulfiati, Suyanto Suyanto, and Hadjar Pamadhi, "Modal Budaya Sebagai Penguat Pembentukan Karakter Berbasis Ajaran Ki Hadjar Dewantara Di Sekolah Dasar," KELUARGA: Jurnal Ilmiah Pendidikan Kesejahteraan Keluarga 5, no. 1 (August 14, 2019): 190-201, https://doi.org/10.30738/keluarga.v5i1.3093. 
Taman Muda Ibu Pawiyatan Primary School of Yogyakarta was established by Ki Hadjar Dewantara (Father of National Education and National Hero) under the auspices of the Majelis Luhur Tamansiswa Foundation. The same thing was also conveyed by Silalahi ${ }^{9}$ who stated that Taman Muda Ibu Pawiyatan Taman Siswa Elementary School, Yogyakarta was the first elementary school founded by Ki Hadjar Dewantara, a national hero in 1922. This elementary school implements character learning through taste, cultural arts, and the application of the among system in the form of a balance between the roles of parents/family, teacher, and community. Besides that, Taman Muda Ibu Pawiyatan Primary School of Yogyakarta has its characteristics that distinguish them from other primary schools. The first characteristic of the schools is to promote the noble character of culture amid the modernization stream as defined in their vision and mission.

Taman Muda Ibu Pawiyatan Primary School of Yogyakarta has the social capital that becomes a driving force to advance education, particularly educational concepts of Ki Hadjar Dewantara called three sentences of education: the family the first environment, the school as the second environment, and the community as the third environment. The three environments are called the Tri Pusat Pendidikan of Ki Hadjar Dewantara. ${ }^{10}$ Tamansiswa also has a harmony between the three educational environments implemented in the context of education. Through college, the content of education informal education is in harmony with family and community education that is non-formal. Thus, the processes of learning can run well if there are networks or strong relationships. Such a networking system connects educational institutions (schools) that utilize the social capital, and they take advantage of the social capital and cooperation with other institutions to support the application of education in an educational unit or institution worth considering. Cooperation is a crucial element in the network.

Character education is designed and developed by different governments in each country. For Indonesia, character education has been designed in a macro and microframework. However, the crisis is based not only on the character of governmental policy on character education, but it must also be considered a socio-cultural approach for the

\footnotetext{
${ }^{9}$ Lucky Astria Silalahi, "Implementasi Pendidikan Budi Pekerti Di Sekolah Dasar Taman Muda Ibu Pawiyatan Tamansiswa Yogyakarta” (Thesis, Yogyakarta, Universitas Negeri Yogyakarta, 2016), http://anjasmara.uny.ac.id/Record/eprints-44586/Details.

${ }^{10}$ Ki Hadjar Dewantara, Buku 1 Pendidikan: Pemikiran, Konsepsi, Keteladanan, Sikap Merdeka (Yogyakarta: UST Press, 2013), 65.
} 
character education process to solve the crisis at the level of community life and social capital approach. ${ }^{11}$

In that sense, this research is urgent because the current character crisis and stunning news-stakes at the national level of life show anti-cultural behaviour, anti-character, and less use of domestic social capital. The social capital needs attention to draw on character education in schools to overcome a character crisis. Most of all, social capital and cultural capital have contributed to improving the progressive efforts of school organizations to allow humans to achieve goals. The social capital can strengthen education in families, schools, and communities in synergy with the inculcation of social capital by sociocultural capital. This paper will examine the role of the social capital of schools in implementing character education and how Ki Hadjar Dewantara's concepts of character education support the social capital in Taman Muda Ibu Pawiyatan Primary School of Yogyakarta.

\section{BACKGROUND AND RELATED RESEARCH}

\section{An Overview of Past Research}

Beginner lecturers' research entitled "The Implementation of Character Education in the School Culture Through the Teachings of Ki Hadjar Dewantara in Taman Muda Ibu Pawiyatan Elementary School of Yogyakarta" in 2016 shows the application of character education through the school culture in the form of the local culture learning, such as dancing, music, artistic painting or drawing, and the learning of Javanese. ${ }^{12}$ Obstacles in implementing character education in school culture lead to advanced information technology being abused by learners. Family factors also play an important role in supervising the behaviour of learners, lack education and people who do not support the achievement of character education goals.

Strengthening the social capital and cultural capital requires further research, referring to the phenomena. Social capital and cultural capital greatly influence character education. Social capital is a social investment obtained from a person's education and

11 S. I. A. Dwiningrum \& Rukiyati. The Social Capital Development For Nation Character Education, (2013), 7

${ }^{12}$ Heri Maria Zulfiati, "Implementation Of Cultural School As Character Education Based On Ki Hadjar Dewantara In Elementary School," in 2017 International Converence on Education and Science (Icons 2017) (Character Development in the 21ST Century Education, Jakarta: Pengurus Besar Persatuan Guru Republik Indonesia (PB PGRI), 2017), 778-92. 
position in the social structure. Social capital contributes to the human capital, familycentred social capital and the role of cognitive development for children, and the level of control. ${ }^{13}$

\section{Theoretical Review}

\section{Ki Hadjar Dewantara's Concepts of Character Education}

Ki Hadjar Dewantara is a modern educational thinker. The Mata Najwa show broadcasted by a private television station on November 26, 2015 showcased a theme "Learning from Ki Hadjar Dewantara". In this TV show, the educational activist Bukik Setiawan said that the thoughts of Ki Hadjar Dewantara strongly remain updated in either his time or beyond his time. A western educational thinker such as Montessori had visited Tamansiswa College in the 1941s to study Ki Hadjar Dewantara's educational system. ${ }^{14}$ Ki Hadjar Dewantara's concepts also have similarities with the education system applied in European countries such as Finland, ${ }^{15}$ which is currently known as the country with the best education system in the world. Seeing this, Indonesia can become a country with a good level of education by referring back to the teachings of Ki Hadjar Dewantara, which are still relevant today.

\section{Understanding Character}

Character aims to support the development of children's life, birth, and mind, from the nature of their nature to the direction of tapping their potentials in the general nature. ${ }^{16}$ Concerning that notion, emphasize that character is interpreted as basic values that build a person's personality because of heredity and environmental factors, distinguishing him or her from others embodied in the attitude and behaviour daily. ${ }^{17}$

\footnotetext{
${ }^{13}$ P. Bourdieu, "The Forms of Capital, In J. Richardson (Ed.)," in Handbook of Theory and Research for the Sociology of Education (New York: Greenwood, 1986); J. Coleman, Social Capital in The Creation of Human Capital. (Cambridge, MA: Harvard University Press, 1999).

${ }^{14}$ Ki Hadjar Dewantara, Buku 1 Pendidikan: Pemikiran, Konsepsi, Keteladanan, Sikap Merdeka (Yogyakarta: UST Press, 2013), 267.

${ }^{15}$ Dwi Kurnianing Ratri, Ahmad Supriyanto, and Ahmad Yusuf Sobri, "Pendidikan Indonesia Di Masa Depan: Tinjauan Kesesuaian Pendidikan Di Finlandia Dengan Ki Hadjar Dewantara," Seminar Nasional Arah Manajemen Sekolah Pada Masa Dan Pasca Pandemi Covid-19, no. 0 (2020), http://conference.um.ac.id/index.php/apfip/article/view/370.

${ }^{16}$ K. H. Dewantara. Education [5 $5^{\text {th }}$ Edition]. (Yogyakarta: UST Press, 2013).

${ }^{17}$ M. Samani \& Hariyanto. Concepts and Models of Character Education (6th ed.). (Bandung: PT. Remaja Rosdakarya, 2017).
} 
Character about learning and instruction, as follows:

"Character consists of operative values, values in action. Character conceived has three interrelated parts: moral knowing, moral feeling, and moral behaviour. Good character consists of knowing the good, desiring the good, and doing the good habits of the mind, habits of the heart, and habits of action". ${ }^{18}$

Based on an explanation from Lickona above, it can be shown that the character is not only limited to knowledge perse, but also treatment or good habituation to shape a good character based on the values for one's personality, but also a treatment or good habituation to shape a good character based on the values for one's personality. AlGhazali coins this term, it articulates morality as a kind behaviour of someone. ${ }^{19}$ In addition, John Dewey (Douglas J. Simpson, et.al: 2005: p.182) ${ }^{20}$ reveals that the teacher loses the position of the external boss or a dictator but takes on that of the leader of group activities. The meaning of Dewey's assertion is that the teacher in the class is not as a dictator who uses the way of indoctrination in conveying knowledge, but the teacher is a leader who carries a moral mandate in front of the students.

Al-Ghazali's term of character can be understood as morality identically. In Zuchdi's notion, the character is a person's universal human behaviour values that encompass all human activities with his God, himself, his fellows, and environment manifested in his daily thoughts, feelings, words, behaviours, and religious norms cultural manners and customs. ${ }^{21}$ As articulated by Fathur Rokhman, et al:

"Education has been considered as the centre of excellence in preparing human's excellent characters. This belief drives every single person to be ready to face global challenges. This belief also becomes the basic foundation for the world to say that Indonesia will be a very strong nation in all sectors in 2045 or 100 years after its independence day". 22

Character is limited to knowledge and treatment and good habituation to form a good character of perceived values that have become parts of a person's personality. Thus,

18 Thomas Lickona. Educating For Character: How Our Schools Can Teach Respect and Responbility. In U. Wahyudin (Ed.) (keempat). (Jakarta: Bumi Aksara, 2015), 51.

19 A. Zainul Fitri, Values \& Ethics-Based Character Education In Schools (Yogyakarta: Ar-Ruzz Media, 2012), 21.

20 Douglas Simpson, “John Dewey's Concept Of The Student," Canadian Journal of Education/Revue Canadienne de l'éducation 26, no. 2 (June 2, 2001): 183-200-183-200, https://journals.sfu.ca/cje/index.php/cje-rce/article/view/2801.

${ }^{21}$ Douglas J. Simpson

${ }^{22}$ Fathur Rokhman et al., "Character Education for Golden Generation 2045 (National Character Building for Indonesian Golden Years)," Procedia - Social and Behavioral Sciences, 4th World Conference on Learning Teaching and Educational Leadership (WCLTA-2013), 141 (August 25, 2014): 1161-65, https://doi.org/10.1016/j.sbspro.2014.05.197 
TRINGA's teachings of Ki Hajar Dewantara deal with affective, cognitive, and psychomotor aspects in education. As usual, education prioritizes the development of cognitive and psychomotor aspects, and it takes heed of an affective aspect that contains character education or character-building. Moreover, it requires learners to be intelligent human beings or the ones who have strong characters. In addition Zulfiati, et al. ${ }^{23}$ mention that The Tri-Nga concept is an educational concept taught by Ki Hajar Dewantara. He defines education as an effort to promote children's character, mind, and body to advance the perfection of life, namely living and reviving children in harmony with nature and society.

\section{Ki Hadjar Dewantara's Teachings}

One of the hallmarks of Tamansiswa is the character education that conceptually becomes Ki Hadjar Dewantara's teachings, as seen from the excerpt of Ki Hadjar Dewantara's writings in Pusara:

"If young children are arrogant, dare to hurt the feelings of their masters and nation, the fruit of teaching and education will not be based on nationality. ... they no longer become children of our nation, nor can we get the nature of a true foreign nation, just a foreign cap. And this is very onnatuurlijk (unnatural)". ${ }^{24}$

In Ki Hadjar Dewantara's view, the purposes of education are to master cognitive skills and other pertinent skills that function as tools and rely on the children's development as human beings in the form of inner and outer necessities of life. Ki Hadjar Dewantara also introduced a term related to family-oriented teaching through Asah, Asih, and Asuh, focusing on nature and independence. This method is implemented along with Tut Wuri Handayani principle and the three centres of education called family, school, and community explains that Tut Wuri means the teacher follows the students' development wholeheartedly based on love unconditionally, without any forces. Ki Hadjar Dewantara emphasized that the three centres of education might be called the teachers' centre because teachers are central figures who seek to provide sciences and

${ }^{23}$ Heri Maria Zulfiati, Suyanto, and Pamadhi Hadjar, "Building The Elementary School Students' Character In 4.0 Era By Implementing TriNga And TriN Concepts In Thematic Learning," International Journal of Recent Technology and Engineering (IJRTE) 8, no. 1C2 (May 2019): 770-75, https://www.ijrte.org/wp-content/uploads/papers/v8i1C2/A11310581C219.pdf.

${ }^{24}$ Ki Hajar Dewantara. Pembahagian Pelajaran Kebangsaan Buat TiapTiap Tingkat Pengajaran. Majalah "Pusara". Edisi Juni1940. Jilid X. no.6 
education, or the centre of the youth movement (natural society) where self-control is important for the formation of character. ${ }^{25,26}$

Lane, et.al ${ }^{27}$ support this insight as cited:

“The relationship between parents and teachers at school will also reflect students' mood, that is, the openness of good relationships between institutions, in this case, school and family that will bring a comfortable atmosphere for children or students. They perform their duties and minimize the potential for emotional instability".

Therefore, character formation through the three centres of education becomes an inseparable thing because family, school, and society repeat habituation in character formation for primary school-age children.

\section{Social Capital Concepts}

Quality education is developed to strengthen social forces or social capital that supports strengthening character education in schools in intra-curricular and extracurricular activities as a form of acceleration of educational innovation.

"Social capital consists of the stock of active connections among people: the trust, mutual understanding, and shared values and behaviours that bind the member of human network and communities and make cooperative action possible." 28

Social capital consists of trust, understanding, and the exchange of values and behaviours that build relationships between individuals and communities that enable mutually beneficial cooperation. "The features of social organization as networks, norms, and social trusts that facilitate coordination and cooperation for mutual benefits". ${ }^{29}$ Social capital becomes the glue for each individual in norms, trust, networks, and cooperation to achieve common goals. Social capital is also understood as shared knowledge and understanding by the community and a pattern of relationships that enables a group of individuals to engage in productive activity.

${ }^{25}$ K. H. Dewantara. Education [5 ${ }^{\text {th }}$ Edition]. (Yogyakarta: UST Press, 2013).

26 Agustinus Hermino, "Peace Education And Child Protection In Educational Settings For Elementary School In The West Papua Of Indonesia,” Asian Social Science 13, no. 8 (July 24, 2017): p20, https://doi.org/10.5539/ass.v13n8p20.

27 Michelle Lane, Rebecca L. Robker, and Sarah A. Robertson, "Parenting From Before Conception," Science, August 15, 2014, https://www.science.org/doi/abs/10.1126/science.1254400.

${ }^{28}$ D. J. Cohen \& L. Prusak. In Good Company How Social Capital Makes Organizations Work. (Cambridge: Harvard Business School Press, 2001)

${ }^{29}$ Robert Putnam, "The Prosperous Community: Social Capital And Public Life," The American Prospect 13, no. Spring), Vol. 4. Available online: http://www. prospect. org/print/vol/13 (accessed 7 April 2003 (1993). 
As Coleman (1990) puts it, social capital is presented resources because it involves the expectation of reciprocity and beyond any individual that involves a wider network with relationships governed by high levels of mutual trusts and values. ${ }^{30}$ Other than that, the social capital associated with Pierre Bourdeu's Habitus theory can be found in several strong indicators of desire, motivation, knowledge, skills, routines, and strategies undertaken at school. ${ }^{31}$ This explanation also means that the internalization of social capital in schools can provide more value and go hand in hand with strengthening character education.

Some experts define social capital as a crucial element to build cooperation between individuals, groups or establish collective and cooperative behaviour. As Coleman $(2013, \mathrm{p} 42)^{32}$ the social capital is inseparable from three basic elements that include (a) trust (honesty, fairness, egalitarian attitudes, tolerance, and generosity); (b) social networks (participation, reciprocity, solidarity, cooperation); (c) norms (common values, norms and sanctions, rules.

The three elements of social capital exist or should exist in the life of a social group, whether the group is called community, society, ethnicity, or other categories. In other words, elements of social capital strengthen the social structure, as illustrated in Figure 1.

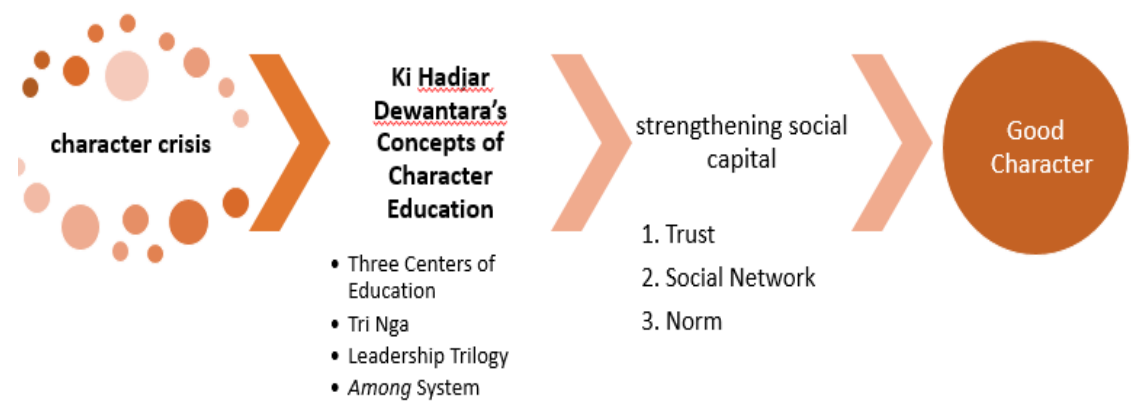

Figure 1

Conceptual Framework

\footnotetext{
${ }^{30}$ James S.Coleman, Foundation of Social Theory (Cambridge, MA: Harvard University Press, 1990).

${ }^{31}$ Sopidi Sopidi, "Integrasi Modal Sosial Dan Budaya Dalam Pengembangan Nilai-Nilai Pendidikan Karakter Di Pondok Pesantren Modern As-Sakinah Sliyeg Indramayu," Holistik 15, no. 2 (March 5, 2016), https://doi.org/10.24235/holistik.v15i2.332.

32 James S. Coleman, Dasar-Dasar Teori Sosial Foundation Of Sosial Theory (Bandung: Nusa Media, 2013).
} 
In addition to some of the references above, several studies relevant to this study have been conducted with different subjects and objects among research conducted by

Kuntoro, Sidiq et al. (2012) ${ }^{33}$, Sumarmo, et al (2011)35 $5^{34}$, Zulfiati, H.M (2016) ${ }^{35}$ Musa Pelu (2015) ${ }^{36}$, Eryanto (2013)38 ${ }^{37}$, Purwanto Antonius (2013) ${ }^{38}$, Kurotul Aeni $(2015)^{39}$ Fitri, Sullivan, A $(2002)^{40}$, and Sopindi $(2014)^{41}$ show that the use of cultural capital in character education in schools has a strategic position in character development efforts. Therefore, this research is more representative to be carried out comprehensively to elaborate the development of character education and the utilization of social capital towards the whole Indonesian people. In addition to some of the research above related to social capital, the thoughts of Ki Hadjar Dewantara's teachings are also very relevant in shaping the character of students, such as research from Marzuki and Siti Khanifah

${ }^{33}$ Sodiq A. Kuntoro, "Menapak Jejak Pendidikan Nasional Indonesia,” in Kearifan Sang Profesor : Bersuku-Bangsa Untuk Kenal-Mengenal, Sismono La Ode and M Rodhi As'ad (Eds.) (Yogyakarta: UNY Press, 2016).

34 Sri Sumarni, Achmad Dardiri, and Darmiyati Zuchdi, "Pengembangan Model Pendidikan Karakter Berbasis Penguatan Modal Sosial Bagi Mahasiswa UIN Sunan Kalijaga," Jurnal Pembangunan Pendidikan: Fondasi Dan Aplikasi 3, no. 1 (July 1, 2015): 44-57, https://doi.org/10.21831/jppfa.v3i1.7811.

${ }^{35}$ Chairiyah Chairiyah, "Implementasi Pendidikan Karakter Melalui Nilai-Nilai Kearifan Lokal Di SD Tamansiswa Jetis Yogyakarta," TRIHAYU: Jurnal Pendidikan Ke-SD-an 4, no. 1 (2017), https://doi.org/10.30738/trihayu.v4i1.2116.

${ }^{36}$ Musa Pelu, Achmad Dardiri, and Darmiyati Zuchdi, "Pendidikan Budi Pekerti Di Sekolah," Jurnal Pembangunan Pendidikan: Fondasi Dan Aplikasi 3, no. 2 (2015): 198-212, https://doi.org/10.21831/jppfa.v3i2.9820.

${ }^{37}$ Henry Eryanto and Darma Rika Swaramarinda, "Pengaruh Modal Budaya, Tingkat Pendidikan Orang Tua Dan Tingkat Pendapatan Orang Tua Terhadap Prestasi Akademik Pada Mahasiswa Fakultas Ekonomi Universitas Negeri Jakarta," Jurnal Pendidikan Ekonomi Dan Bisnis (JPEB) 1, no. 1 (March 29, 2013): 39-61, https://doi.org/10.21009/JPEB.001.1.3.

${ }^{38}$ Antonius Purwanto, "Modal Budaya Dan Modal Sosial Dalam Industri Seni Kerajinan Keramik," MASYARAKAT: Jurnal Sosiologi 18, no. 2 (October 8, 2015): 233-61, https://doi.org/10.7454/mjs.v18i2.3727.

${ }^{39}$ Kurotul Aeni, Zamroni Zamroni, and Darmiyati Zuchdi, "Pendayagunaan Modal Sosial Dalam Pendidikan Karakter," Jurnal Pembangunan Pendidikan: Fondasi Dan Aplikasi 4, no. 1 (December 21, 2016): 30-42, https://doi.org/10.21831/jppfa.v4i1.9819.

${ }^{40}$ Alice Sullivan, "Bourdieu And Education: How Useful Is Bourdieu's Theory For Researchers?," Netherlands Journal of Social Sciences 38, no. 2 (2002): 144-66, https://www.researchgate.net/profile/Alice-

Sullivan/publication/283919595_Bourdieu_and_Education_How_useful_is_Bourdieu's_theory_for_resea rchers/links/5734a85c08aea45ee83ad851/Bourdieu-and-Education-How-useful-is-Bourdieus-theory-forresearchers.pdf.

${ }^{41}$ Sopidi Sopidi, "Integrasi Modal Sosial Dan Budaya Dalam Pengembangan Nilai-Nilai Pendidikan Karakter Di Pondok Pesantren Modern As-Sakinah Sliyeg Indramayu," Holistik 15, no. 2 (March 5, 2016), https://doi.org/10.24235/holistik.v15i2.332. 
$(2016)^{42}$, and Mutoifin and Mutohharun Jinan $(201543)^{43}$, showing that social capital has a contribution. Positive towards the world of education.

\section{RESEARCH METHODS}

This research is descriptive qualitative research along with its naturalistic paradigm of the case study. A case study is a naturalistic approach that has some features: a) using an actual setting (an actual circumstance), b) a descriptive qualitative research, c) qualitative research that prefers the processes rather than results, d) qualitative research that tends to analyze inductively, and e) the "meaning" in qualitative research is a major concern. ${ }^{44}$

This research was conducted at Tamansiswa Primary School, Yogyakarta, Indonesia. This place was chosen as the research location because it applied the educational concepts of Ki Hadjar Dewantara and the availability of information sources that could support researchers. At the same time, the research time frame occurred from November 2017 to January 2018. This research was conducted until the data obtained were saturated considerably.

The selection of research subjects was specifically based on purposive sampling relevant to the research design. The data sources of this research consist of Primary data sources and secondary data sources. Primary data sources consist of a) Principal; b) teachers of grade IV, V, and V, amounting to three teachers; c) representatives of highclass students of grade IV, V, and VI (each level consists of 5 students); d) School committees, as well as parent representatives, amounting nine persons; e) the foundation board members, amounting, three persons.

This research used the techniques of participant data collection, in-depth interviews, and documentation. The instrument was researchers as key instruments, but they needed other instruments as guidelines to implement the research in observation and interview

${ }^{42}$ Marzuki Marzuki, "Revitalisasi Pendidikan Agama Di Sekolah Dalam Pembangunan Karakter Bangsa Di Masa Depan,” Jurnal Pendidikan Karakter, no. 1 (2013): 121902, https://journal.uny.ac.id/index.php/jpka/article/view/1288.

${ }^{43}$ Muthoifin Muthoifin and Mutohharun Jinan, "Pendidikan Karakter Ki Hadjar Dewantara: Studi Kritis Pemikiran Karakter Dan Budi Pekerti Dalam Tinjauan Islam," Profetika: Jurnal Studi Islam 16, no. 2 (December 17, 2015): 167-80, https://doi.org/10.23917/profetika.v16i2.1852.

${ }^{44}$ Robert C. Bogdan and Biklen Kopp Sari, Qualitative Research for Education: An Introduction to Theory and Methods (London: Allyn and Bacon, Inc., 1982). 
guidelines. All instruments are directed to determine the role of social capital in strengthening character education in schools.

The results of the research can be accounted for from all sides. The validity of data in this research include the test of internal validity (credibility), external validity (transferability), reliability (dependence), and objectivity (confirmability). At the same time, data analysis techniques used interactive models from Miles and Huberman, including three types of analyses and data collections, reductions, and displays of conclusions verifiably.

\section{RESULT AND DISCUSSION \\ RESULT}

\section{The Role of Social Capital in Implementing Character Education in Taman Muda Ibu Pawiyatan Primary School of Yogyakarta}

Like a good educational institution, SD Tamansiswa Jetis Yogyakarta has social capital that can be a driving force in advancing education. One of the educational concepts from $\mathrm{Ki}$ Hadjar Dewantara is the Tri Education Center, namely family as the first environment, school as the second environment, and society as the third environment. In Tamansiswa, in addition to the Tripusat education as harmony between the three educational environments in its implementation, it is also in the content of education. Through college, the content of school/college education informal education is harmonized with informal family education and community education, which is non-formal. Thus the process and implementation can run well if supported by strong networks or relationships. The network or relationship can be optimized if the educational institution (school) can take advantage of the social capital. These educational institutions (schools) can take advantage of the social capital they have. Collaboration with other institutions to support education in an educational unit or institution also needs to be considered. Cooperation is a very important element in the network itself.

As a school established by Ki Hadjar Dewantara, Taman Muda Ibu Pawiyatan Primary School of Yogyakarta becomes a social capital in implementing the concept of character education, as can be seen from the interview with the Headmaster of Mrs An:

"The implementation of social capital in schools is carried out through the living organ of kinship organization; for example, there is a close relationship, mutual respect, mutual help, and strive for each member's prosperous and happy life together (Mamayu Hayuning Salira, Bangsa and Manungsa)" (An interview, 22 February 2018). 
The Headmistress's insight was further reinforced by Mrs. Acb, Mrs. LR, and Mr. TR, who said:

“... the utilization of social capital in Ki Hadjar Dewantara's perspectives deals with the character education in a family system and mutual love (Asih, Asah, Asuh). In addition, the education centres are a complete system implemented in family, school, and society. The three components must complement each other. Ki Hajar Dewantara also coined a so-called educational trilogy that embodies a leadership principle, i.e., Ing Ngarsa Sung Tuladha, Ing Madya Mangun Karsa, Tut Wuri Handayani " (An Interview, February 23, 2018).

The statement from the Principal was also reinforced by Mrs. Acb, Mrs. LR and Mr. TR, who said:

"The utilization of social capital in the perspective character education of Ki Hadjar Dewantara uses a family system, loving each other (compassion, sharpening, and nurturing). In addition, Ki Hajar Dewantara taught about "tri pusat pendidikan" that education is a complete system carried out in the family, school, and community. These three components must complement one another. Ki Hajar Dewantara also teaches the educational trilogy, namely Ing Ngarsa Sung Tuladha, Ing Madya Mangun Karsa, Tut Wuri Handayani; based on the statement above, it can be concluded that the use of social capital at SD Taman Muda Ibu Pawiyatan and SD Tamansiswa Jetis Yogyakarta uses a family system both at school, family and community, namely by loving each other, mutual respect, cooperation and help".

The utilization of social capital in Taman Muda Ibu Pawiyatan Primary School has provided fertile ground for a familial system in school, family, and community through which mutual love, respect, appreciation, and help are worth inculcating.

\section{DISCUSSION}

SD Tamansiswa Jetis Yogyakarta has social capital that can be a driving force in advancing education. The existence of social capital in the school shows that its school is a good educational institution. One of the educational concepts from Ki Hadjar Dewantara is the Tri Education Center, namely family as the first environment, school as the second environment, and society as the third environment. In Tamansiswa, in addition to the Tripusat education as harmony between the three educational environments in its implementation, it is also in the content of education. Through college, the content of school/college education informal education is harmonized with informal family education and community education, which is non-formal. Thus the process and implementation can run well if supported by strong networks or relationships. The network or relationship can be optimized if the educational institution (school) can take 
advantage of the social capital. These educational institutions (schools) can take advantage of the social capital they have. Collaboration with other institutions to support education in an educational unit or institution also needs to be considered. Cooperation is a very important element in the network itself.

The implementation of the concept of thought Ki Hadjar Dewantara through the strengthening of social capital looks in Table 1.

Table 1

The Role of Social Capital in the Character Education: Ki Hadjar Dewantara's Perspectives

\begin{tabular}{|c|c|c|c|c|}
\hline \multirow{2}{*}{$\begin{array}{c}\text { Components } \\
\text { of Social } \\
\text { Capital } \\
\end{array}$} & \multirow[b]{2}{*}{ Description } & \multicolumn{3}{|c|}{ The Education Centers } \\
\hline & & Family & School & Community \\
\hline Trust & $\begin{array}{l}\text { Character } \\
\text { education } \\
\text { extremely } \\
\text { requires trust in } \\
\text { generating } \\
\text { social } \\
\text { interaction } \\
\text { processes. The } \\
\text { trust among } \\
\text { schools, } \\
\text { teachers, } \\
\text { foundations, } \\
\text { employees, } \\
\text { parents, and } \\
\text { communities } \\
\text { aims to build the } \\
\text { students' } \\
\text { character. }\end{array}$ & $\begin{array}{l}\text { A family is the } \\
\text { main place for } \\
\text { the children's } \\
\text { character } \\
\text { building through } \\
\text { the inculcation } \\
\text { of moral and } \\
\text { religious values, } \\
\text { and so forth. } \\
\text { Parents' trust } \\
\text { and upbringing } \\
\text { approach } \\
\text { determine } \\
\text { children's } \\
\text { success in } \\
\text { fulfilling } \\
\text { psychological } \\
\text { needs. }\end{array}$ & $\begin{array}{l}\text { In principle, } \\
\text { school is not a } \\
\text { "transfer of } \\
\text { knowledge" } \\
\text { place, but it } \\
\text { makes efforts } \\
\text { to prioritize } \\
\text { values and } \\
\text { character- } \\
\text { oriented } \\
\text { learning } \\
\text { activities }\end{array}$ & $\begin{array}{l}\text { Communities } \\
\text { introduce } \\
\text { insights and } \\
\text { knowledge and } \\
\text { provide } \\
\text { opportunities to } \\
\text { develop } \\
\text { children's } \\
\text { abilities and } \\
\text { skills beyond } \\
\text { family and } \\
\text { school contexts. }\end{array}$ \\
\hline Network & $\begin{array}{l}\text { School } \\
\text { networking is } \\
\text { developed as a } \\
\text { model of } \\
\text { support for Ki } \\
\text { Hadjar } \\
\text { Dewantara's } \\
\text { concepts and } \\
\text { existing social } \\
\text { networking that } \\
\text { in not limited to } \\
\text { the same social } \\
\text { class. }\end{array}$ & $\begin{array}{l}\text { Family and } \\
\text { school } \\
\text { committees } \\
\text { support each } \\
\text { school's policy; } \\
\text { for example, the } \\
\text { school } \\
\text { committee } \\
\text { initiates open } \\
\text { school activities } \\
\text { to recruit new } \\
\text { students. }\end{array}$ & $\begin{array}{l}\text { The school } \\
\text { cooperates } \\
\text { with many } \\
\text { parties to } \\
\text { inculcate the } \\
\text { character- } \\
\text { building } \\
\text { involving the } \\
\text { police } \\
\text { department, } \\
\text { National } \\
\text { Narcotics } \\
\text { Agency } \\
\text { (BNN). }\end{array}$ & $\begin{array}{l}\text { The } \\
\text { communities' } \\
\text { active } \\
\text { participation, in } \\
\text { this case, is un- } \\
\text { optimal because } \\
\text { Taman Muda } \\
\text { Ibu Pawiyatan } \\
\text { Primary School } \\
\text { is located on the } \\
\text { main street and } \\
\text { far from the } \\
\text { citizens' } \\
\text { settlements. }\end{array}$ \\
\hline
\end{tabular}




\begin{tabular}{|c|c|c|c|c|}
\hline \multirow{2}{*}{$\begin{array}{c}\text { Components } \\
\text { of Social } \\
\text { Capital }\end{array}$} & \multirow[b]{2}{*}{ Description } & \multicolumn{3}{|c|}{ The Education Centers } \\
\hline & & Family & School & Community \\
\hline Norm & $\begin{array}{l}\text { Character } \\
\text { education } \\
\text { requires social } \\
\text { norms that play } \\
\text { an important } \\
\text { role in } \\
\text { controlling } \\
\text { character-based } \\
\text { behaviors in the } \\
\text { family, school, } \\
\text { and society. The } \\
\text { school-based } \\
\text { norms draw on } \\
\text { Ki Hadjar } \\
\text { Dewantara's } \\
\text { wise words and } \\
\text { principles. }\end{array}$ & $\begin{array}{l}\text { Family plays a } \\
\text { vital role in } \\
\text { determining the } \\
\text { children's } \\
\text { building through } \\
\text { the discussion } \\
\text { and consensus, } \\
\text { resulting in } \\
\text { children's good } \\
\text { behaviors to } \\
\text { generate a } \\
\text { strong } \\
\text { foundation of } \\
\text { democracy and } \\
\text { politeness } \\
\text { toward parents, } \\
\text { guests. }\end{array}$ & $\begin{array}{l}\text { School uses } \\
\text { cooperative } \\
\text { values, norms, } \\
\text { sanctions, and } \\
\text { rules through a } \\
\text { government- } \\
\text { designed code } \\
\text { of conduct. } \\
\text { School } \\
\text { provides } \\
\text { students with } \\
\text { commands, } \\
\text { forces, and } \\
\text { punishments } \\
\text { for violations } \\
\text { against the law } \\
\text { that threaten } \\
\text { life safety and } \\
\text { harmony. }\end{array}$ & $\begin{array}{l}\text { The surrounding } \\
\text { community, as } \\
\text { the third centre } \\
\text { of education } \\
\text { after school and } \\
\text { family, play a } \\
\text { crucial role in } \\
\text { fostering } \\
\text { existing norms, } \\
\text { including the } \\
\text { community- } \\
\text { based advantage } \\
\text { of school for } \\
\text { children, } \\
\text { institutional } \\
\text { decisions, } \\
\text { involvement in } \\
\text { societal decision } \\
\text { making, } \\
\text { discussions of } \\
\text { academic and } \\
\text { non-academic } \\
\text { topics }\end{array}$ \\
\hline
\end{tabular}

Sources: Compiled from the primary data, 2018

Based on the table above, it can be seen that the role of social capital in Taman Muda Ibu Pawiyatan Primary School has provided fertile ground for a familial system in school, family, and community through which mutual love, respect, appreciation, and help are worth inculcating. Broadly speaking, social capital is a crucial element for building up cooperation between individuals and groups or establishing collective and cooperative behavior. The social capital is inseparable from the three basic elements that include (a) trust (honesty, fairness, egalitarian attitudes, tolerance, and generosity); (b) social networks (participation, reciprocity, solidarity, cooperation), and (c) norms (common values, norms and sanctions, rules). Observations and interviews strongly indicate that schools have understood the existence and role of social capital for improving the quality of education and a driving force of character formation. However, this social capital has not been evaluated as an important part of social capital improvement. 
Character education will run well and succeed if synergy exists between the three education centers or Tri Pusat Pendidikan involving education in the family environment, the school environment, and the social environment. This finding is mainly concerned with the results of interviews with principals who articulate that character education will not work well if it capitalizes social capital owned by the school per se. Therefore, the social capital must be developed comprehensively. The existence of education centres affects the growth process (an interview, February 23, 2018). This statement is reinforced by research results that have an important role in children's education, concluded that this study has provided new information about the role of parenting style and parents concluded that education is in a positive state of adolescent youth development in Malaysia, strongly recommended for the future. ${ }^{45}$ In line with Ki Hadjar Dewantara's notions and interviews with related experts concerning the role of the Tri Pusat Pendidikan, it points out that school does not deal with the inculcation of character education perse. However, societies and families also educate children using the character education framework. ${ }^{46}$ Thus, the character building of primary school-aged children through the three education centres is an inseparable thing because in the formation of character education, it is necessary to pay attention to habituation starting from the family, school, and community.

\section{CONCLUSION}

As a school established by Ki Hadjar Dewantara, Taman Muda Ibu Pawiyatan Primary School of Yogyakarta has a social capital in implementing character education based on Ki Hadjar Dewantara's perspectives applied well in all learning processes, both intra-curricular and extracurricular domains. In the contextual school culture, the family system is integrated into the habituation and exemplary in school and society through mutual love, respect, appreciation, and help. The elements of social capital that strengthen character education building are trust, norm, and network.

45 A Kiadarbandsari et al., "Role of Parenting Style and Parents' Education in Positive Youth Development of Adolescents.," Pertanika Journal of Social Sciences \& Humanities 24, no. 4 (2016), http://psasir.upm.edu.my/id/eprint/50865/1/Role\%20of\%20Parenting\%20Style\%20and\%20Parents'\%20E ducation\%20in\%20Positive\%20Youth\%20Development\%20of\%20Adolescents.pdf.

46 Thomas Lickona. Educating For Character: How Our Schools Can Teach Respect and Responbility. In U. Wahyudin (Ed.) (keempat). (Jakarta: Bumi Aksara, 2015), 34. 
Observations and interviews show that schools have understood the existence and role of social capital for improving the quality of education as a driving force to shape character education. However, this social capital has not been evaluated as an important part of social capital improvement. As a school established by Ki Hadjar Dewantara, Taman Muda Ibu Pawiyatan Primary School of Yogyakarta has a role of social capital in fostering character education based on Ki Hadjar Dewantara's perspectives, and it has been applied well in all learning processes, both intra-curricular and extracurricular domains. In the contextual school culture, the family system is an integral part of habituation and exemplary for school and community mutually replete with love, respect, appreciation, and help. The elements of social capital fostering character education are trust, norm, and network.

Recommendations for future researchers are that it is hoped that further researchers can expand studies related to social capital to strengthen character education in schools. In addition, other researchers can also try to research by applying social capital according to the teachings of Ki Hadjar Dewantara in schools other than schools under Tamansiswa so that the teachings of Ki Hadjar Dewantara can be internalized in other schools.

\section{ACKNOWLEDGMENTS}

Universitas Sarjanawiyata Tamansiswa Yogyakarta.

\section{DECLARATION OF CONFLICTING INTERESTS}

I hereby declare that the author has no potential conflict of interest in connection with the research, authorship, and/or publication of this article.

\section{FUNDING}

Private funds were used to support this research.

\section{ORCID iD}

Heri Maria Zulfiati id https://orcid.org/0000-0001-9122-6301

Biya Ebi Praheto

Anselmus Sudirman 


\section{REFERENCES}

Aeni, Kurotul, Zamroni Zamroni, and Darmiyati Zuchdi. "Pendayagunaan Modal Sosial Dalam Pendidikan Karakter." Jurnal Pembangunan Pendidikan: Fondasi Dan Aplikasi 4, no. 1 (December 21, 2016): 30-42. https://doi.org/10.21831/jppfa.v4i1.9819.

Bogdan, Robert C. and Biklen Kopp Sari. Qualitative Research for Education: An Introduction to Theory and Methods. London: Allyn and Bacon, Inc., 1982.

Bourdieu, P. The forms of capital. In J. Richardson (Ed.) Handbook of Theory and Research for the Sociology of Education. New York: Greenwood, 1986.

Chairiyah, Chairiyah. "Implementasi Pendidikan Karakter Melalui Nilai-Nilai Kearifan Lokal Di SD Tamansiswa Jetis Yogyakarta." TRIHAYU: Jurnal Pendidikan KeSD-an 4, no. 1 (2017). https://doi.org/10.30738/trihayu.v4i1.2116.

Cohen, D. J. \& Prusak, L. In Good Company How Social Capital Makes Organizations Work. Cambridge: Harvard Business School Press, 2001.

Coleman, J. S. Social Capital in The Creation of Human Capital. Cambridge: Harvard University Press, 1999.

Coleman, J. S. Foundation of Social Theory. Cambridge, MA: Harvard University Press, 1990.

Coleman, J. S. Dasar-Dasar Teori Sosial Foundation Of Sosial Theory. Bandung: Nusa Media, 2013.

Dewantara, K. H. Pembahagian Pelajaran Kebangsaan Buat TiapTiap Tingkat Pengajaran. Majalah "Pusara”. Edisi Juni1940, Jilid X, No.6.

Dewantara, K. H. Buku 1 Pendidikan: Pemikiran, Konsepsi, Keteladanan, Sikap Merdeka. Yogyakarta: UST Press, 2013.

Dwiningrum, Siti Irene Astuti. "Nation's Character Education Based on the Social Capital Theory." Asian Social Science 9, no. 12 (October 30, 2013): p144. https://doi.org/10.5539/ass.v9n12p144.

Dwiningrum, S. I. A. \& Rukiyati. The Social Capital Development For Nation Character Education. Lumbung Pustaka Universitas Negeri Yogyakarta (2013).

Eryanto, Henry, and Darma Rika Swaramarinda. "Pengaruh Modal Budaya, Tingkat Pendidikan Orang Tua Dan Tingkat Pendapatan Orang Tua Terhadap Prestasi Akademik Pada Mahasiswa Fakultas Ekonomi Universitas Negeri Jakarta." Jurnal Pendidikan Ekonomi Dan Bisnis (JPEB) 1, no. 1 (March 29, 2013): 39-61. https://doi.org/10.21009/JPEB.001.1.3.

Fitri, A. Z. Values \& Ethics-based Character Education in Schools. Yogyakarta: Ar-Ruzz Media, 2012.

Hermino, Agustinus. "Peace Education And Child Protection In Educational Settings For Elementary School In The West Papua Of Indonesia." Asian Social Science 13, no. 8 (July 24, 2017): p20. https://doi.org/10.5539/ass.v13n8p20.

Kiadarbandsari, A, Z Madon, HH Hamsan, and K Mehdinezhad Nouri. "Role of Parenting Style and Parents' Education in Positive Youth Development of Adolescents." 
Pertanika Journal of Social Sciences \& Humanities 24, no. 4 (2016). http://psasir.upm.edu.my/id/eprint/50865/1/Role\%20of\%20Parenting\%20Style\% 20and\%20Parents'\%20Education\%20in\%20Positive\%20Youth\%20Developmen t\%20of\%20Adolescents.pdf.

Kuntoro, Sodiq A. "Menapak Jejak Pendidikan Nasional Indonesia.” In Kearifan Sang Profesor: Bersuku-Bangsa Untuk Kenal-Mengenal, Sismono La Ode and M Rodhi As'ad (Eds.). Yogyakarta: UNY Press, 2016.

Lane, Michelle, Rebecca L. Robker, and Sarah A. Robertson. "Parenting From Before Conception." Science, August 2014. https://www.science.org/doi/abs/10.1126/science.1254400.

Lickona, T. Educating For Character: How Our Schools Can Teach Respect and Responsibility (4 ${ }^{\text {th }}$ Eds.). Jakarta: Bumi Aksara, 2015.

Marzuki, Marzuki. "Revitalisasi Pendidikan Agama Di Sekolah Dalam Pembangunan Karakter Bangsa Di Masa Depan.” Jurnal Pendidikan Karakter, no. 1 (2013): 121902. https://journal.uny.ac.id/index.php/jpka/article/view/1288.

Muthoifin, Muthoifin, and Mutohharun Jinan. "Pendidikan Karakter Ki Hadjar Dewantara: Studi Kritis Pemikiran Karakter Dan Budi Pekerti Dalam Tinjauan Islam.” Profetika: Jurnal Studi Islam 16, no. 2 (December 17, 2015): 167-80. https://doi.org/10.23917/profetika.v16i2.1852.

Pelu, Musa, Achmad Dardiri, and Darmiyati Zuchdi. "Pendidikan Budi Pekerti Di Sekolah.” Jurnal Pembangunan Pendidikan: Fondasi Dan Aplikasi 3, no. 2 (2015): 198-212. https://doi.org/10.21831/jppfa.v3i2.9820.

Purwanto, Antonius. "Modal Budaya Dan Modal Sosial Dalam Industri Seni Kerajinan Keramik.” MASYARAKAT: Jurnal Sosiologi 18, no. 2 (October 8, 2015): 233-61. https://doi.org/10.7454/mjs.v18i2.3727.

Putnam, Robert. "The Prosperous Community: Social Capital And Public Life." The American Prospect 13, no. Spring), Vol. 4. Available online: http://www. prospect. org/print/vol/13 (accessed 7 April 2003 (1993).

Ratri, Dwi Kurnianing, Ahmad Supriyanto, and Ahmad Yusuf Sobri. "Pendidikan Indonesia Di Masa Depan: Tinjauan Kesesuaian Pendidikan Di Finlandia Dengan Ki Hadjar Dewantara." Seminar Nasional Arah Manajemen Sekolah Pada Masa Dan Pasca Pandemi Covid-19, no. 0 (2020). http://conference.um.ac.id/index.php/apfip/article/view/370.

Rokhman, Fathur, M. Hum, Ahmad Syaifudin, and Yuliati. "Character Education for Golden Generation 2045 (National Character Building for Indonesian Golden Years)." Procedia - Social and Behavioral Sciences, 4th World Conference on Learning Teaching and Educational Leadership (WCLTA-2013), 141 (August 25, 2014): 1161-65. https://doi.org/10.1016/j.sbspro.2014.05.197.

Samani, M. \& Hariyanto. Concepts and Models of Character Education (6th ed.). Bandung: PT. Remaja Rosdakarya, 2017.

Silalahi, Lucky Astria. "Implementasi Pendidikan Budi Pekerti Di Sekolah Dasar Taman Muda Ibu Pawiyatan Tamansiswa Yogyakarta." Thesis, Universitas Negeri Yogyakarta, 2016. http://anjasmara.uny.ac.id/Record/eprints-44586/Details. 
Simpson, Douglas. "John Dewey's Concept Of The Student." Canadian Journal of Education/Revue Canadienne de l'éducation 26, no. 2 (June 2, 2001): 183-200183-200. https://journals.sfu.ca/cje/index.php/cje-rce/article/view/2801.

Sopidi, Sopidi. "Integrasi Modal Sosial Dan Budaya Dalam Pengembangan Nilai-Nilai Pendidikan Karakter Di Pondok Pesantren Modern As-Sakinah Sliyeg Indramayu." Holistik 15, no. 2 (March 5, 2016). https://doi.org/10.24235/holistik.v15i2.332.

Sumarni, Sri, Achmad Dardiri, and Darmiyati Zuchdi. "Pengembangan Model Pendidikan Karakter Berbasis Penguatan Modal Sosial Bagi Mahasiswa UIN Sunan Kalijaga." Jurnal Pembangunan Pendidikan: Fondasi Dan Aplikasi 3, no. 1 (July 1, 2015): 44-57. https://doi.org/10.21831/jppfa.v3i1.7811.

Sullivan, Alice. "Bourdieu And Education: How Useful Is Bourdieu's Theory For Researchers?" Netherlands Journal of Social Sciences 38, no. 2 (2002): 14466.https://www.researchgate.net/profile/Alice-

Sullivan/publication/283919595_Bourdieu_and_Education_How_useful_is_Bou rdieu's_theory_for_researchers/links/5734a85c08aea45ee83ad851/Bourdieuand-Education-How-useful-is-Bourdieus-theory-for-researchers.pdf.

Suyanto. Social Capital. News: Kedaulatan Rakyat. June 2017.

Wardani, K. \& Sumiyati, Y. "Implementasi Pendidikan Karakter Melalui Pengelolaan Modal Sosial pada Pembelajaran di Sekolah Dasar." Seminar Nasional Riset Inovatf II. Jakarta: Universitas Mercubuana, 2014, 222-229. http://digilib.mercubuana.ac.id/manager/t! @file_artikel_abstrak/Isi_Artikel_235 856818721.pdf.

Zulfiati, Heri Maria. "Implementation Of Cultural School As Character Education Based On Ki Hadjar Dewantara In Elementary School." In 2017 International Converence on Education and Science (Icons 2017), 778-92. Jakarta: Pengurus Besar Persatuan Guru Republik Indonesia (PB PGRI), 2017.

Zulfiati, Heri Maria, Suyanto, and Pamadhi Hadjar. "Building The Elementary School Students' Character In 4.0 Era By Implementing TriNga And TriN Concepts In Thematic Learning." International Journal of Recent Technology and Engineering (IJRTE) 8, no. 1C2 (May 2019): 770-75. https://www.ijrte.org/wpcontent/uploads/papers/v8i1C2/A11310581C219.pdf.

Zulfiati, Heri Maria, Suyanto Suyanto, and Hadjar Pamadhi. "Modal Budaya Sebagai Penguat Pembentukan Karakter Berbasis Ajaran Ki Hadjar Dewantara di Sekolah Dasar.” KELUARGA: Jurnal Ilmiah Pendidikan Kesejahteraan Keluarga 5, no. 1 (August 14, 2019): 190-201. https://doi.org/10.30738/keluarga.v5i1.3093. 
The Role Of Social Capital...

This page is intentionally left blank 